\title{
TRADE UNION RECOGNITION IN MALAYSIA: LEGAL ISSUES
}

\author{
Siti Suraya Abd Razak \\ International Islamic University Malaysia, Malaysia \\ E-mail: alsuraya87@yahoo.com \\ Nik Ahmad Kamal Nik Mahmod \\ International Islamic University Malaysia, Malaysia \\ E-mail:nahmad@iium.edu.my
}

Abstract: In Malaysia, the Federal Constitution protects the worker's enjoyment as to freedom of association, in particular, the right to form and join the trade union. However, due to security purposes, various restrictions have been imposed on trade union activities. The recognition process is currently showing a decline in the number of recognition awards due to the government's policy. This paper examines the legal issues and challenges confronting the trade union in the recognition process in Malaysia. This study adopted the qualitative approach to analyse the statutory procedures and cases relating to the issue. Interviews were conducted with the Department of Industrial Relations, Malaysia and the Department of Trade Union Affairs, Malaysia to obtain their opinion on the recognition process. It is suggested that the Malaysian government should abolish the employer's recognition; provide a statutory definition on the managerial, executive, confidential and security positions; establish an independent administrative trade union board and ratify the Convention Concerning Freedom of Association and Protection of the Right to Organise Convention No. 87.

Keywords: Trade union, Recognition process, ILO Convention No. 87, Freedom of association.

Abstrak: Di Malaysia, Perlembagaan Persekutuan melindungi kebebasan pekerja untuk berpersatuan, terutamanya, hak pekerja untuk menubuhkan dan menyertai kesatuan sekerja. Pelbagai sekatan telah dibuat ke atas aktiviti kesatuan sekerja demi faktor keselamatan. Kesan daripada polisi kerajaan, jumlah pengiktirafan 
yang berjaya menunjukkan kemerosotan. Kajian ini mengkaji isu undang-undang dan cabaran yang dihadapi oleh kesatuan sekerja dalam proses pengiktirafan kesatuan sekerja di Malaysia. Kajian ini menggunakan kaedah kualitatif untuk menganalisis prosedur-prosedur Akta dan kes-kes mahkamah yang berkaitan. Temu bual di Jabatan Perhubungan Perusahaan Malaysia dan Jabatan Kesatuan Sekerja telah dijalankan untuk mendapatkan pendapat mereka tentang proses pengiktirafan kesatuan sekerja secara keseluruhannya. Kajian ini mencadangkan supaya kerajaan Malaysia memansuhkan pengiktirafan majikan; memberikan definisi akta terhadap pengurusan, eksekutif, sulit dan keselamatan; menubuhkan badan bebas untuk menguruskan kesatuan sekerja serta mengiktiraf Konvensyen Kebebasan Persatuan dan Perlindungan Hak Menganjur No.87.

Kata Kunci: Kesatuan sekerja, Proses pengiktirafan, Konvensyen 87 \& Kebebasan persatuan.

\section{INTRODUCTION}

A trade union is an essential mechanism for a worker to exercise his or her right on collective bargaining with the employer. The rights and welfare of the members in the workplace such as proper wages, security of employment, reasonable hours and conditions of work can be improved through the voice of a trade union movement. For a trade union to function, freedom of association must first be guaranteed as the fundamental right of a state. At the international stage, the International Labour Organisation ('ILO') recognise the freedom of association as one of the four Core Labour Standards. ${ }^{1}$ ILO also adopted the Convention Concerning Freedom of Association and Protection of the Right to Organise Convention

There are four Core Labour Standards laid down in eight conventions. Firstly, the elimination of all forms of forced or compulsory labour (Conventions Nos. 29 and 105), the abolition of child labour (Conventions Nos. 138 and 182), freedom of association and the effective recognition of the right to collective bargaining (Conventions Nos. 87 and 98) and fourth, the elimination of any discrimination in employment and occupation and the recognition of equal remuneration for work of equal value (Conventions Nos. 100 and 111). 
No. 87 (ILO Convention No. 87) in 1948 to preserve the rights of workers to form and join an association of their choosing. ${ }^{2}$

In Malaysia, the freedom of association is prescribed in the Federal Constitution $^{3}$. The worker in Malaysia is allowed to form and join a trade union. However, it is not absolute. Malaysia's experience on the communist's threat had taught the state government to control the trade union activities for the security of the Federation. ${ }^{4}$ Therefore, various restrictions have been imposed on the trade union movement for the nation's interest. Unfortunately, the limits have contributed to the lengthy and complicated trade union recognition process, and it directly impedes the trade union's right to collective bargaining. ${ }^{5}$

At present, the recognition of trade union in Malaysia is governed by the Trade Unions Act 1959 ('TUA 1959') and Industrial Relations Act 1967 ('IRA 1967'). A trade union is defined under TUA as any worker's organisation or employer's organisation within any particular establishment trade, occupation or industry or within any similar trades, occupations or industries, whether temporary or permanent and having the objects listed under the provision as part of its trade union constitution. ${ }^{6}$ For a trade union to participate in the collective bargaining process with the employer, the trade union must register according to the prescribed rules. ${ }^{7}$ A trade union that wishes to represent a group of workers of similar trade, industry or occupation must fulfil the conditions listed under Section 9 of IRA 1967 before they can participate in the collective bargaining with the employers. The statutory period indicates that it takes around nine months to settle a recognition claim. ${ }^{8}$

2 International Labour Organisation, 'About the ILO', http://www.ilo.org, Article 10(1)(c) of the Federal Constitution.

Article 10(2)(c) of the Federal Constitution states that restrictions can be imposed as the government deem it is necessary and expedient in the interest of the security of the federation, for public order or morality and Article 10(3) allow restrictions being made to the area of labour and education.

5 Kim WY (1976) 'The Communist Challenge in the Malayan Labour Scene, September 1936- March 1937' Journal of the Malaysian Branch of the Royal Asiatic Society, Vol. 49, No. 2 (230).

6 Section 2(1) of the TUA 1959 on the definition of 'trade union.'

7 Section 2(1) of the IRA 1967.

8 According to the maximum period stated under the procedures of Industrial Rules and Regulations 2009. 


\begin{tabular}{lccccc}
\hline Outcome & 2012 & 2013 & 2014 & 2015 & 2016 \\
\hline $\begin{array}{l}\text { Recognition granted } \\
\text { voluntarily by the } \\
\text { employer }\end{array}$ & 10 & 9 & 15 & 6 & 2 \\
$\begin{array}{l}\text { Recognition granted } \\
\text { by Minister's } \\
\text { decision }\end{array}$ & 29 & 30 & 25 & 18 & 17 \\
$\begin{array}{l}\text { Recognition not } \\
\text { ordered by Minister }\end{array}$ & 25 & 15 & 29 & 30 & 17 \\
$\begin{array}{l}\text { Recognition } \\
\text { rejected/withdrawn/ } \\
\text { union not eligible/ } \\
\text { fault }\end{array}$ & 43 & 43 & 40 & 51 & 32 \\
\hline
\end{tabular}

Source. Statistics and key indicators in 2016, Department of Industrial Relations, Malaysia

Table 1 indicates that the Malaysian trade union faced challenges in the recognition process. There was a decline in the number of recognition claims being awarded to the trade union in Malaysia between 2012 and 2016. In 2016, only two employers agreed to recognise the trade union. The result also showed that the Minister had awarded the lowest number of recognition claims in 2016. In the light of the above result, this paper examines and analyses legal challenges in the trade union recognition process in Malaysia.

\section{OBJECTIVES}

The objectives of this research is first, to identify the legal issues and challenges surrounding the trade union recognition process and to propose amendments to the rules and regulations and laws relating to the trade union recognition process in Malaysia.

\section{RESEARCH METHODOLOGY}

The research methodology of this study was purely qualitative. The protocol employed was by way of critical analysis of statutes 
and rules that included the IRA 1967, IRR 2009 and TUA 1959. Besides that, a descriptive analysis on trade union recognition law through the study of journal articles, websites, newspaper articles and conference proceedings was carried out to investigate the issues in this study. This study also examined the Malaysian courts' decisions concerning trade union recognition. Finally, the article also discussed the outcome of interviews with officers of the Department of Industrial Relations, Malaysia and the Department of Trade Union Affairs, Malaysia.

\section{LEGAL ISSUES CONCERNING TRADE UNION RECOGNITION IN MALAYSIA}

\section{Employer's Recognition}

An overview of the flow of the recognition process in Malaysia will provide the legal framework. Part III of the IRA 1967 and Part II of the Industrial Relations Regulations 2009 ('IRR 2009') describe the rules and regulations for the recognition of a trade union in Malaysia. The first step requires the trade union that wishes to represent the workers in the collective bargaining to submit an application form together with the Union's Constitution to the employer and the DGIR ${ }^{9}$. Within 21 days after the receipt of such documents, the employer can voluntarily recognise the trade union. ${ }^{10}$ If the employer rejected the claim or if there is no reply made after the period has lapsed, the trade union can lodge a report to the DGIR. ${ }^{11}$ In performing his duties, the DGIR will take the necessary steps to ascertain the eligibility of the trade union to represent the workers. The DGIR has the authority to refer the case to the Director General of Trade Unions ('DGTU') for him to conduct a competency check on the trade union ${ }^{12}$. After the DGTU has deemed that a trade union is competent, the DGIR shall conduct a secret ballot to determine that the majority of the workers support the trade union or otherwise. ${ }^{13}$ Finally, the Minister of Human Resource will decide whether to refuse or to accord recognition to the trade union. ${ }^{14}$

\footnotetext{
Regulation 3 of IRR 2009

Section 9(3)(a) of IRA 1967

Section 9(3A) of IRA 1967

Section 9(4B)(b) of the IRA 1967

Regulation 9 of IRR 2009

Section 9(5) of IRA 1967
} 
The lengthy and complicated procedures are a challenge for a trade union to efficiently function, as the employer's recognition is a prerequisite before the trade union can participate in the collective bargaining. Anti-union practices of employers in avoiding collective bargaining can further aggravate the situation. Evidence of such practice is the case of Sabah Forest Industries ('SFI') whereby the employer has consistently filed for judicial reviews since 2003 to deny recognition of the trade union. ${ }^{15}$ The DGIR contended that the employer was the cause of the delay in the recognition process, first, by rejecting the claim for recognition, issuing objections and making an application(s) to the High Court for judicial reviews. The grounds of complaints and the basis for judicial review application were technical matters such as spelling mistakes in the application form, the absence of the employer in the secret ballot meeting and the defective service of notices. ${ }^{16}$

\section{DGTU's Power in the Competency Check}

The DGIR must refer to the DGTU for competency check. Competency check in the recognition process was outlined clearly by the court in the case of Minister of Labour \& Manpower $v$ Paterson Candy (M) Sdn Bhd ${ }^{17}$ Namely, the workers must be within any similar trades, occupations or industries as written in the trade union's constitution. In respect of 'similarity' for a trade, occupation or industry, it must be 'similar' according to the opinion of the DGTU. It is a standard practice in the DGIR's office to conduct a competency check although it is not mandatory in the Regulations. The respondents further contended that the competency check could prevent the employer from resorting to objections and judicial reviews that will further delay the recognition process. ${ }^{18}$

The objective of the implementation of this provision can be traced back to the introduction of TUA 1959 in 1940 when the communist movement and ideology were a threat to the colonial government.

\footnotetext{
15 International Trade Union Confederation (2016) 2016 ITUC Global Rights Index - Malaysia, 9 June 2016, available at http://www.refworld.org/docid/5799aa66c. html

16 Personal interview with officer from Department of Recognition Investigation, Department of Industrial Relations, Malaysia (JPPM), November 13, 2017. [1980] 2 MLJ 122

18 Personal interview with officer from Department of Recognition Investigation, Department of Industrial Relations, Malaysia (JPPM), November 13, 2017.
} 
The authority enacted the TUA 1959 to curb the communist influence amongst the trade unions. The concern was the establishment of a robust omnibus trade union that consisted of workers from multiple industries and occupations that could substantially affect industrial harmony and posed a threat to the economy. Thus, the enactment of the new law was intended to segregate workers' union based on industry and occupation and would result in the small and less influential workers' movement in the industry. By dividing the trade unions into different categories, any suspicious activities that may cause harm to the state can be immediately identified by the authorities. The government feared that omnibus unions might be led by persons having nothing to do with the professional activities or interests represented by the organisation's political or even subversive aims. ${ }^{19}$

Competency check of the trade union is not against the principle of freedom of association. However, the DGTU's decisions on the 'similarity' issue are subject to challenge in the courts. There are some judicial review applications recording objections to the decisions made by the DGTU arising from claims for recognition. For example, in the case of Kesatuan Kebangsaan Pekerja-Pekerja Syarikat-Syarikat Pembuatan Keluaran Getah v YB Menteri Sumber Manusia \& Anor ${ }^{20}$, Rule 3(c) of the National Union of Employees in Companies Manufacturing Rubber Products' (NUECMRP) Constitution provided that the workers must engage in manufacturing rubber products to become members of the trade union. Following the non-feedback from the employer, the trade union lodged a report to the DGIR. The Minister refused to grant recognition to the trade union on the grounds that it was not competent to represent the workers. The trade union challenged the Minister's decision at the High Court. The Court referred to Rule 3(c) of the Union's Constitution and the nature of the employer's business, and agreed with the Minister's decision by not granting the trade union with recognition because the workers were engaged in the manufacturing and repacking of medical products made of only $3.0 \%$ rubber and $97.0 \%$ non-rubber materials. For the NUECMRP to represent the

\footnotetext{
19 Personal interview with officer from Department of Registration and Recognition Investigation, Department of Trade Union Affairs (JHEKS), October 2, 2017.

20 [2012] MLJU 620
} 
workers, the court emphasised that workers must prove that their work involved producing rubber products that contained more than $51 \%$ rubber materials.

In the latest case of Kesatuan Kebangsaan Pekerja-Pekerja Perusahaan Alat-Alat Pengangkutan dan Sekutu v Menteri Sumber Manusia \& Anor ${ }^{21}$, the workers' right to be represented by a national union was denied on the grounds that the workers did not belong to a similar industry within the scope of the Union's Constitution. Rule 3(c) of the National Union of Transport Equipment and Allied Industries Workers' (NUTEAIW) Constitution provides that the workers must engage in companies dealing with manufacturing, assembling and repairing of motor vehicles, motorcycles, bicycles, tractors, bulldozers, parts and manufacturing accessories for motor vehicles to fall within the representation of the NUTEAIW. The DGTU argued that the membership is for workers that engage in activities producing the basic parts that are essential to the running of a motor vehicle. Furthermore, the DGTU's investigation revealed that the goods produced by the employer's activities were not finished products because the employer would send the goods to other countries for further processing to become complete and usable products. Based on these facts, the High Court dismissed the judicial review application.

The discretion given to the DGTU in the claims for recognition has been a subject for debate because of the broad discretion that the law confers on him/her to determine whether the trade union belongs to the similar trades, occupations and industries of the employees. In one occasion, the Federal Court in the case of Electrical Industry Workers Union v Registrar of Trade Unions ${ }^{22}$ had declined to interfere with the DGTU's discretionary powers in determining the competency of the trade union and also refused to draw up any guideline for the exercise of power. According to the respondents, the DGTU is the appropriate authority to determine the issue of similarity as he is acting as a mediator in the recognition claim between the trade union and the employer. ${ }^{23}$ The mediation

\footnotetext{
$21 \quad$ [2016] MLJU 1215

$22 \quad[1976] 1$ MLJ 177

23 Personal interview with officer from Department of Registration and Recognition Investigation, Department of Trade Union Affairs (JHEKS), October 2, 2017.
} 
function is part of the industrial harmony process where the neutral DGTU is acting in the best interest of both parties. In the course of executing his role, the DGTU does not act arbitrarily as his office carries out investigations such as making visits to the workplace, and organising interview sessions with both workers and employers. In the course of the inquiry, the DGTU collects relevant information and sets out criteria to decide on the issue of competency. ${ }^{24}$ However, it is a contentious issue whether the DGTU is categorically an expert on the industry in question, to determine the competency of the trade union.

\section{Majority Representation}

Before conducting the secret ballot, the DGIR must first satisfy that the trade union has the capacity by way of the majority support to represent the workers. The law requires that if the trade union is representing the general employees, the trade union shall not have members who are in the managerial capacity, executive capacity, confidential capacity and the security capacity ("the four categories'). ${ }^{25}$ Nonetheless, the four categories of workers may establish their trade union within their categories that have similar capacities and interests. The DGIR's office is to investigate the membership list before finalising the list of workers eligible to participate in the secret ballot. ${ }^{26}$

There is no statutory interpretation for the four categories of workers. The correct test to determine their competencies is outlined in the case of HSBC Bank Malaysia v Menteri Sumber Manusia, Malaysia $\&$ Anor $^{27}$. According to the judge, in assessing whether the workers fall into the four categories, the Minister should make reference to their job title and job description instead of job grade as the latter cannot be used as indicia, reference point and/or yardstick to determine whether the workers are employed in the four categories. Challenging the recognition claim on the abovementioned ground has become prevalent for the employer. When workers' scope of duties differs from one business organisation to another, employers

\footnotetext{
24 Ibid

25 Section 9(1) of IRA 1967

26 Regulation 7 of IRR 2009

27 [2012] MLJU 630
} 
tend to exploit the position in various ways. For instance, employers employ tactics such as restructure job positions in their respective organisations and thereby, question the voting capacity of the workers. The respondent claimed that in some cases, the employer refused to cooperate and deliberately delayed the submission of the list of workers to the DGIR despite the 14 days deadline given to them under Regulation 6 of the IRR 2009. ${ }^{28}$

In the case of Ambank (M) Berhad v Menteri Sumber Manusia \& Anor and another appeal ${ }^{29}$, the Association of Bank Officers Peninsular Malaysia ('ABOM') submitted a recognition claim to Ambank (M) Berhad to represent the workers under the position of Executive Scale E. The employer requested the DGIR to carry out a membership check by conducting a secret ballot. The secret ballot result indicated that 210 workers were within the Executive Scale E category. ABOM invited the bank to participate in the collective bargaining with the Executive Scale E workers, but the bank refused the invitation on the grounds that ABOM had expanded the scope of the categories by including workers from Executive Scales: E1, E2 and E3 in the bargaining process. The employer accused the trade union of an attempt to generalise and then sought the benefit of a wider interpretation of the categories. On the other hand, ABOM alleged that the bank's accusation was an attempt to forestall the trade union's recognition claim as the denial of the scope of representation was an 'afterthought' by the employer. The Court of Appeal allowed the Bank's appeal on the grounds of the Minister's failure "to not make any in-depth analysis or ask the right questions in determining the scope of representation". The Court decided that ABOM had to make a separate recognition claim to the employer in representing the different categories of Executive Scale E workers. In the case of Heritage Lane Sdn Bhd v YB Menteri Sumber Manusia, Malaysia \& $A n o r^{30}$, the employer declared to the DGIR that the Group Drivers (who were part of the group of employees seeking recognition as a trade union), fell under the security category, and thus, the Group Drivers were disqualified as members of the trade union.

28 Personal interview with officer from Department of Registration and Recognition Investigation, Department of Trade Union Affairs (JHEKS), October 2, 2017

29 [2014] 6 MLJ 377

30 [2017] MLJU 484 


\section{Ratification of ILO Convention No. 87}

Although Malaysia subscribes to the philosophy of the Universal Declaration of Human Rights, she has yet to ratify and become signatory to the various international human rights conventions. ${ }^{31}$ Malaysia has shown its commitment as an ILO member state by ratifying five out of the eight fundamental labour rights conventions. ${ }^{32}$ To date, the government is still reluctant to ratify the ILO Convention No. 87. The government in its reply to the ILO governing body stated that the main reason for not conforming to the ILO Convention No. 87 is that 'it would enable the formation of general unions, which might be led by persons having nothing to do with the activities or interests of unions, and pursuing political or even subversive aims'. ${ }^{33}$ Malaysia also stresses that although she has not ratified the ILO Convention No. 87, Article 10(1) of the Federal Constitution preserves the right to form and join a trade union. The right to collective bargaining is recognised as Malaysia has ratified the ILO Convention No. 98. Workers are free to engage in collective bargaining with the employer without interference except in situations 'affecting the security, public order and economic wellbeing of the nation'. ${ }^{34}$

The government aims to produce a 'disciplined' and 'responsible'trade union movement for the sake of national security. ${ }^{35}$ The Government

31 Out of fifteen international human rights instruments, Malaysia only confirms five of the conventions. Accessed from http://indicators.ohchr.org/ on $7 / 3 / 2018$.

32 The eight core conventions under ILO are Forced Labour Convention No. 29, Freedom of Association and the Protection of the Right to Organise Convention No. 87, Right to Organise and Collective Bargaining Convention No. 98, Equal Remuneration Convention No. 100, Abolition of Forced Labour Convention No. 105, Discrimination (Employment and Occupation) Convention No. 111, Minimum Age Convention No. 138, Worst Forms of Child Labour Convention No. 182.

33 The Government's Reply to Report No. 333, March 2004, Case No. 2301 (Malaysia) accessed from http://www.ilo.org/dyn/normlex/en/f?p=1000:50002 :0::NO:50002:P50002_COMPLAINT_TEXT_ID:2908253 on 3/3/2018

34 The Government's Reply to Report No. 248, March 1987, Case No. 1380 (Malaysia) accessed from http://www.ilo.org/dyn/normlex/en/f?p=1000:50002 :0::NO:50002:P50002_COMPLAINT_TEXT_ID:2901531 on 3/3/2018

35 The Government's Reply to Report No. 177, June 1978, Case No. 879 (Malaysia) accessed from http://www.ilo.org/dyn/normlex/en/f?p=1000:50002 :0::NO:50002:P50002_COMPLAINT_TEXT_ID:2900048 on 3/3/2018 
of Malaysia in its report to the ILO mentioned that the convention is 'not relevant to its national situation and historical background' and therefore, the ratification of the ILO Convention No. 87 is not the state's priority. ${ }^{36}$ The provisions under the ILO will directly reduce state interference in trade union formation and activities, and this does not commensurate with the Malaysian government's national security policy. From the government's perspective, providing an easy passage for the workers to make demands for high wage structures seems to be an unattractive package for foreign investors. This situation will affect the government's effort to build an advanced economy by the year 2020 .

\section{RECOMMENDATIONS}

The above scenarios highlight the need for changes in the policy and law on trade union recognition. The Malaysian government should review existing practices and consider amending the law to achieve a fair and effective trade union recognition process. First and foremost, the government should consider removing the DGTU's discretionary power to determine the competency of the trade union. Instead, the government should create an independent body to administer the process of trade union recognition and trade union activities. Such a body that manages all trade union matters can be seen in Canada, where the government established the Canada Industrial Relations Board $^{37}$ and the Fair Work Commission ${ }^{38}$ in Australia. The countries' board and commission have memberships of experts, representatives from worker's organisation and employer's organisation in their panels. An independent body dealing with issues such as the recognition of trade unions is essential to ensure transparency and fairness.

\footnotetext{
36 Obstacles to ratification and prospects (2012) Giving Globalisation a Human Face. International Labour Conference $101^{\text {st }}$ Session Part VI. pp 372

37 Canada, Industrial Relations Board, accessed from http://www.cirb-ccri.gc.ca/ eic/site/047.nsf/eng/home

38 Rae Cooper, Bradon Ellem and Patricia Todd, 'Workers' Rights and Labour Legislation:Reviving Collective Bargaining in Australia' (Paper presented at International Labour and Employment Relations Association 16th World Congress, Philadelphia,5 July 2012) pp 5
} 
The government should also consider abolishing the requirement for employer's recognition of a workplace trade union. Developed countries such as Australia, applies the 'automatic recognition' mechanism. ${ }^{39}$ Under this practice, once the trade union is registered, it will automatically have the right to be the bargaining agent of the workers in the collective bargaining process. By eliminating this rule, the employer's formidable anti-union tactic can be overcome. If the abolition of the recognition process is not forthcoming, it is pertinent for Parliament to define the scope of the four categories of workers so that it will pre-empt the employer's exploitation of the provisions.

It is plain to see that the statutes are inadequate to preserve the rights of the workers to form and join the trade union in Malaysia. As the first step, the Malaysian government should ratify the ILO Convention No. 87, and that would require a substantial reform to trade union policies. As a member of the ILO, Malaysia should abide by the preamble of the ILO Constitution, which needs its member states to discharge their responsibilities to promote the principle of freedom of association. ${ }^{40} \mathrm{Abolishing}$ the recognition process is perhaps the first step forward.

It has been said that there is a dire need to review the IRA 1967 and the TUA 1959 as the Acts are archaic. ${ }^{41}$ Despite the state's need to be vigilant of the threat of communism or other extreme ideologies spreading to workers in trade unions which may threaten national security, the government should respect the worker's right to associate by liberalising the recognition process and encouraging employers to recognise the trade union. Collective bargaining should be viewed as a partnership rather than an adversarial process between the trade union and the employer. This effort is vital to propel Malaysia to developed nation status. ${ }^{42}$

\footnotetext{
$39 \quad$ Ibid pp 6

40 Article 19(5)(e) of ILO Constitution makes it compulsory for ILO member states to report on unratified conventions to the ILO.

41 Voon Shian (2010) 'Malaysia Labour Law Review' available at www.meca. com.my

42 N Gopal Kishnam (2016) 'MTUC: Implement reforms of labour laws regardless of TPPA's uncertainty.' available at http://www.malaysiakini.com/ letters/363336
} 


\section{CONCLUSION}

In conclusion, it can be observed that the worker in Malaysia is free to form and join a trade union. However, the existing provisions require amendments and improvements in dealing with the issues raised in the said discussion.

\section{REFERENCES}

Ambank (M) Berhad v Menteri Sumber Manusia \& Anor and another appeal [2014] 6 MLJ 377

Electrical Industry Workers Union v Registrar of Trade Unions [1976] 1 MLJ 177

Heritage Lane Sdn Bhd v YB Menteri Sumber Manusia, Malaysia \& Anor [2017] MLJU 484

HSBC Bank Malaysia v Menteri Sumber Manusia, Malaysia \& Anor [2012] MLJU 630

ILBS. (2013). Industrial Relations Act. Kuala Lumpur: ILBS Publication.

ILBS. (2013). Trade Unions Act, Kuala Lumpur: ILBS Publication International Trade Union Confederation (2016) 2016 ITUC Global Rights Index - Retrieved from http://www.refworld.org/ docid/5799aa66c.html

International Trade Union Confederation, 2015 ITUC Global Rights Index - Malaysia. Retrieved from http:/www.refworld.org/ docid/557a9a0f34.html

Kesatuan Kebangsaan Pekerja-Pekerja Syarikat-Syarikat Pembuatan Keluaran Getah v YB Menteri Sumber Manusia \& Anor [2012] MLJU 620.

Kesatuan Kebangsaan Pekerja-Pekerja Perusahaan Alat-Alat Pengangkutan dan Sekutu v Menteri Sumber Manusia \& Anor [2016] MLJU 1215.

Kim, W. Y. (1976). The communist challenge in the Malayan labour scene, September 1936-March 1937, Journal of the Malaysian Branch of the Royal Asiatic Society, 49(2), 230.

Ministry of Human Resource. (2017). Interview with officer in the Department of Industrial Relations.

Ministry of Human Resource. (2017). Interview with officer in the Department of Trade Union Affairs.

Minister of Labour \& Manpower v Paterson Candy (M) Sdn Bhd [1980] 2 MLJ 122. 
MTUC. (2016). Intervention needed to dethrone the Judicial Review King, Retrieved from http://www.mtuc.org.my/interventionneeded-to-dethrone-the-judicial-review-king/

N Gopal Kishnam. (2016). MTUC: Implement reforms of labour laws regardless of TPPA's uncertainty. Retrieved from http:// www.malaysiakini.com/letters/363336

Obstacles to ratification and prospects. (2012). Giving Globalisation a Human Face International Labour Conference $101^{\text {st }}$ Session Part VI.

Rae Cooper, Bradon Ellem \& Patricia Todd, Workers' rights and labour legislation: Reviving collective bargaining in Australia. Paper presented at International Labour and Employment Relations Association 16th World Congress, Philadelphia.

Statistics and Key Indicators. (2016). Department of Industrial Relations, Malaysia.

Voon Shian. (2010). Malaysia Labour Law Review' retrieved from www.meca.com.my

Yee Fong. (1992). The impact of the Cold War on the development of trade unionism in Malaya (1948-57). Journal of Southeast Asian Studies, 23, 1. 